\title{
Possible Selves, Motivation, and Classroom Practices: A Qualitative Enquiry with English Teachers in Dhaka, Bangladesh
}

\author{
Beauty Debnath \\ Directorate of Secondary and Higher Secondary Education, Dhaka, Bangladesh
}

\begin{abstract}
Studies around the world show that students' motivation for learning English as a foreign language is usually interconnected with teachers' motivation. To explore this relationship, this study investigated five Bangladeshi EFL teachers' early language learning experiences, their visions of possible L2 selves, their motivations for becoming English teachers and the way they connect their visions with their classroom teaching for motivating students. This study employed L2 Motivational Self System (Dorney, 2005, 2009) as the theoretical framework. It was situated in the constructivist paradigm using a qualitative approach taking the form of a narrative enquiry. Data was collected from teachers' language biographies and in-depth interviews. The thematic analysis of data revealed teachers' considerable academic and socio-cultural challenges, their improved motivational states and visions of either 'Ideal L2 Self' or 'L2 Learning Experiences'. Teachers with 'Ideal L2 Selves' were found more aware of generating students' L2 vision. The study also found a considerable influence of social, economic, psychological, infrastructural, and cultural factors on teachers' professional motivation and commitment. Therefore, the study has brought implications for addressing these factors at an institutional and political level to bring about attitudinal change towards teaching as a profession in Bangladesh.
\end{abstract}

Index Terms-L2 motivation, possible selves, L2 vision, classroom practice, EFL teachers, EFL students

\section{INTRODUCTION}

Motivation is the paramount driving force for second language learning, and, without adequate motivation, even remarkably able students can fail to obtain desired goal (Dorney, 1990). It is widely observed that students do not appear to have the motivation to learn English in Bangladesh (Ahmad, 2005; Hussain \& Masum, 2016; Quadir, 2017). Studies have shown lack of internal motivation to be the cause of deterioration in students' English proficiency in Bangladesh (Alam 2001; Quadir 2017; Kabir 2015). Winchester's (2012) study suggests that teachers can play a vital role in the co-construction, communication and legitimization of learners' identities and motivation in the classrooms differently. In the teacher-centred classroom in Bangladesh, teachers have considerable influence on students' motivation for learning. If the teacher is positively motivated to teach, she/he might effectively contribute to generating motivation and interest among learners. Learners' early experiences shape their attitudes and determine their motivation for further investment in the target language (Ushioda's, 1998). Her study explored the notion that individuals' patterns of motivation emerged from their language learning experiences, which may include a positive learning history and target language environment. A study on Bangladeshi teachers' perception of their possible L2 selves and motivation for learning and teaching could therefore provide insight into their professional practices. Thus, it is important to investigate teachers' motivational backgrounds.

\section{A. The Background Study}

1) English language teachers and teaching in Bangladesh: English education in Bangladesh suffers from an acute shortage of competent and trained English teachers. According to Haq (2004), the scarcity of EFL teachers discourages all aspirations. Again, most of the course books produced by the National Curriculum and Textbook Board (NCTB) do not address the English curriculum. Repeated changes in pedagogy and syllabi over the last decade have also been frustrating (Ahmed, 2005). Instead of the traditional Grammar-Translation method (GTM), the Communication Language teaching (CLT) approach is the new expected method of instruction, but lack of infrastructural and technological support, scarcity of trained teachers, inappropriate learning materials and insufficient learning resources cannot support CLT in Bangladesh. Moreover, the assessment system in Bangladesh also adversely affects L2 proficiency. A review by Sultana (2018) found that, English public examination at SSC level has failed to address the objectives of learning and teaching English in Bangladesh.

2) Students' motivation for English language learning in Bangladesh: Students' demotivation for L2 learning is a crucial concern for language teachers and educators in Bangladesh (Ahmad, 2005; Hussain \& Masum, 2016; Quadir, 2017). According to Dornyei (2001), demotivation is "specific external forces that reduce or diminish the motivational basis of a behavioural intention or an ongoing action" (p.143). Quadir's (2017) study found that both external and 
internal factors impact on learners' motivation. These include students' past experiences, access to learning resources, school environment, and socio-economic status of family and teachers' performance in the classroom. In secondary school context, 95\% of the student respondents in Quadir's (2017) study reported that, demotivating aspects were related to teachers' practice of EFL teaching. Her study identified three categories of practice: (i) Teachers' instructional style; (ii) Teachers' attitude/personality, and (iii) Teachers' competence. She also identified teachers' low effort to motivate students, lack of guidance about improving language proficiency, and incompetence in providing organised instructions in class (Quadir, 2017).

\section{B. Research Questions}

Researchers in Bangladesh (e.g., Das, 2001; Maniruzzaman \& Haque, 2000; Rahman, 2005, 2007; Shahed, 2000; Sultana, 2014; Sil, 2017; Quadir, 2017) have conducted studies on L2 motivational issues. Most of these studies have focused on students' motivation and teachers' use of motivational strategies in the classroom. However, there has been no systematic investigation into teachers' attitudinal and motivational orientations. So, there remains a noticeable niche in the research literature. Therefore, this study aims to explore EFL teachers' language learning experiences, their perception of possible selves, motivation for learning and teaching English, and how they relate their visions to their classroom practices. To address these issues, this study will explore four research questions:

1. What language learning experiences do Bangladeshi EFL teachers bring to the English classroom?

2. What vision of possible L2 selves do the teachers in the study hold?

3. How are their visions related to their motivations to be English teachers?

4. How do they relate their visions to their classroom practice to motivate students?

\section{Rationale of the Study}

To address this crisis of demotivation, the teacher can play an essential role by engaging students in their long L2 learning journey. Teachers' motivation for L2 learning and teaching should have an explicit influence on their efforts in motivating students. Scholarly discussions most often concern students' motivation and attitudes, but the same areas for EFL/ESL teachers are scarcely touched upon. It would be enlightening to see the other side of the coin as well. Perhaps, all teachers are not equally motivated to learn and teach English. Motivating students to learn English is a mammoth task for teachers in Bangladesh where socio-educational, socio-cultural and socio-economic conditions create considerable impediments. If a teacher has been a demotivated L2 learner or had low motivation for becoming a teacher, she/he cannot be reasonably expected to motivate students in the best possible ways. Teachers' own English language learning experiences, their L2 visions, and motivations may be projected into their classroom practices. Increased understanding of how EFL teachers perceive their motivational orientations through their stories of their L2 vision and motivation for learning and teaching may provide a lens through which to view English teachers' motivational realities in Bangladesh.

\section{The Theoretical Development in L2 Motivation And ReVIEW of TEACHer Motivation ResearCH}

\section{A. Motivation and L2 Motivation}

Motivation is an abstract and complex concept applied to explain human behaviour (Gardner, 2010). It triggers an individual's action to achieve a desired goal (Cook \& Artino, 2016). Motivation is considered to be a fundamental factor in the L2 learning process. Dornyei (1998) defined motivation as an impetus to initiate L2 learning and later it acts as the driving force to sustain the long and tedious process of learning. A resurgence of interest in motivational issues in second language learning appeared during the 1990s and it involved extensive debate and discussions about the nature and dimensions of motivation (Dornyei,1994a, 1994b; Gardner \& Tremblay, 1994; Oxford, 1994; Oxford \& Shearin,1994). The lack of consensus about the motivational variables involved in L2 learning has originated different motivational constructs. The variations include the integrative-instrumental dichotomy developed by Gardner and Lambert in 1959; intrinsic and extrinsic orientations in Deci and Ryan's (1985) Self-determination theory; Gardner's socio-educational model of L2 motivation and L2MSS by Dornyei $(2005,2009)$. Similarity can be perceived between all the theories although the robust discussions on this topic have given birth to diverse theoretical frameworks.

\section{B. Possible Selves Theory}

The concept of self was previously perceived as a static and unitary accrual of self-knowledge from the individual's past experiences (Markus \&Wurf, 1987, p. 9). However, the perception of self has been applied in diverse fields of teacher education and education in general since Markus and Nurius (1986) developed a multifaceted future-oriented self-concept and termed it 'possible selves' (Fletcher, 2000). Possible selves refer to themselves that one believes one might become in the near or distant future. According to Markus and Nurius (1986), Possible self indicates the ideal self that one would like to become, selves that one could become as well as the selves one is afraid of becoming. Possible selves serve as motivators to shape an individual's action and behaviour to fulfil what one desires to become and stay away from what one is afraid of becoming. The motivators provide "a context of additional meaning for the current behaviour of the individual" (Markus \& Nurius, 1986, p. 955). This concerns the fact that possible selves incorporate 
senses and tangible images (Dornyei, 2009). These images are advantageous to framing future goals and engaging in goal-oriented action (Markus \& Ruvolo, 1989).

\section{L2 Motivational Self-system (L2MSS)}

Dornyei $(2005,2009)$ developed his L2MSS by incorporating ideas from both Markus and Nurius's Possible self and Higgin's Self-discrepancy theory. It drew on the notion that learners' vision of their future selves provides the motivational impetus for L2 learning (Peng, 2015). The three main constructs of L2MSS comprise the 'Ideal L2 self', the 'Ought -to Self' and the 'L2 Learning experience'. He suggested that the 'Ideal self' is the most significant selfconstruct in his framework, as the gap between one's desire to be a fluent L2 speaker and one's current self-acts as a self-guide which serves as the motivator to reduce the discrepancy. Success in L2 learning grows proportionately with a learner's motivation to reduce this discrepancy. The three self-constructs can be explained in the following ways:

The Ideal L2 Self: The Ideal L2 self' refers to the L2-specific facet of one's 'Ideal self' (Dornyei, 2009,). It indicates what an individual would desire, aspire or like to be. It represents a language learner's ideal image or vision for the future. This kind of image of a future self act as a positive psychological stimulator and accelerates the learning process.

Ought to L2 Self: This self-construct concerns what one is extrinsically motivated to learn from a sense of compulsion or imposition to avoid possible negative consequences.

L2 Learning Experience: This construct concerns learners' attitudes and experiences of teachers' influence, curriculum, peer group and the learning process inside and outside of the classroom (Lamb, 2017). This motivational dimension is related to the learning situation rather than the self-image.

\section{Review on the Empirical Studies on ESL/EFL Teacher Motivation}

Second language acquisition (SLA) researchers have demonstrated a consistent interest in motivation (Ushioda, 2009). In the historical hierarchy, L2 motivational research has shifted its attention from macro-level to a micro-level of study. Understanding teachers' roles has become a significant concern for exercising considerable influences on learners' motivation (Han, 2017). Research work on teachers' idea of L2 self, vision, and motivation in ESL teaching context is relatively scarce. Empirical studies by Kubanyiova (2009), White and Ding (2009), Sugino (2010), Kumazawa (2013), Hiver (2013), Wyatt (2013), Thompson and Vasquez (2015), Rahmati, Sadeghi, and Ghaderi (2018) have focused on teachers' motivation in different ESL/EFL contexts.

A qualitative study conducted on EFL teachers in Slovakia by Kubanyiova (2009), used Dornyei's L2MSS as a conceptual framework to explore EFL teachers' development. The study revealed discrepancies between the teachers' vision and the educational reality. Moreover, the study revealed the dissonance between teachers' ideals and educational reality acting as detrimental to teachers' motivation and professional commitment (Kubanyiova, 2009).

Kumazawa (2013) investigated four inexperienced Japanese teachers' motivational status by employing Markus and Nurius's (1986) "Possible selves" theory. The narrative analysis of data from interviews explored the need of teacher training. Kumazawa's research found that the shocking gap between teachers' job expectations and the realities they experienced caused their low motivation for EFL teaching.

White and Ding (2009) shed light on how the concepts of the ideal self and ought-to self influenced and was influenced by the engagement of language teachers in e-learning. This investigation revealed the significant role of possible selves as influential motivators for the language teachers who were trying to execute changes to their teaching methods.

Hiver (2013) conducted a narrative study on in-service EFL teachers' possible selves. Hiver explored how the possible self constructs of ideal, ought-to and feared selves worked as motivators. Three teachers who were lowproficiency users of English, demonstrated a high level of feared selves. The other four proficient teachers showed strong ideal selves. The study revealed that the teacher's sense of the discrepancies between their actual selves and ideal selves worked as a motivator to develop.

Rahmati, Sadeghi, and Ghaderi (2018) explored EFL teachers' vision and motivation in Iran drawing on 'possible selves' theory and activity theory in their mixed-method study. Applying a semi-structured interview for qualitative and a questionnaire for the quantitative phase, the study revealed a positive relationship between $(r=.59)$ vision and motivation. The study brought implications for teacher education programs to raise teachers' awareness and motivational force of vision.

The methodological implications evolved from the related literature situated this study in a constructivist paradigm using qualitative approach. According to Bada and Olusegun (2015, p. 66) constructivism stands for a process of 'mental construction' of ideas. It suggests that we construct meaning and knowledge from our own experiences and encounters in real life as well as our reflections on them (Bereiter, 1994). It is important for educators to be familiar with the concepts of constructivism and their implications for teaching and teachers' professional development (Tam, 2000). This paradigmatic stance will help this study to construct an in-depth understanding about the teachers' experiences as language learners in Bangladesh.

\section{Methodology}


In qualitative research, the selection of participants is purposeful (Maxwell, 2005; Seidman, 2006; Stake, 2005). To address the study objectives, five participants who teach English at colleges (public or private) in Dhaka for more than two years, received English education in Bangladesh and are Bangladeshi by birth, were selected.

The selected participants are Priam, Mohan, Fima, Shormi, and Neha (pseudonyms). The author went through her personal and professional networks to identify them. The scholarship conditions made a compulsion to rely on online communication media (email and Skype) to contact the participants. For the participants' busy work-schedules, their availability was quite challenging. However, they took time to write their narratives on language learning and later took part in the in-depth interviews for 40-50 minutes each.

TABLE 1

PROFILE OF THE PARTICIPANTS

\begin{tabular}{|c|c|c|c|c|c|}
\hline Feature & Priam & Mohan & Fima & Shormi & Neha \\
\hline Age & 45 years & 35 years & 40 years & 30 years & 29 years \\
\hline Gender & Male & Male & Female & Female & Female \\
\hline Job Title & Assistant & Lecturer & Assistant & Assistant & Lecturer \\
& Professor & & Professor & Professor & \\
\hline Degree & PhD, MA in & MA in & MA in & MA in & MA in \\
& English & English & English & English & English \\
& Literature & Language and & Literature & Language & Literature, \\
& & Master of \\
& & Literature & & & Education \\
& & & & & \\
& & & & & Private \\
& Public & Public & Public & Private & College \\
\hline Working & College, & College, & College, & Dhaka & \\
\hline Place & Dhaka & Dhaka & Dhaka & Dhaka & 2 years \\
\hline Experience & 18 years & 9 years & 17 years & 6 years & \\
\hline
\end{tabular}

\section{B. Data Collection}

The primary source was narrative writing in which the participants reflected their language learning experiences and the other was in-depth interviews. Narrative writing has the potential to elicit participants' perception of their possible selves (Whitty, 2002). For drawing out teachers' real-life experiences of their L2 learning journey, L2 vision and motivational factors, the participants were asked to write their language learning history with some prompts provided. An extensive reading of the participants' narratives was done to identify any gaps in data required to meet the research questions. To complete the gaps in the narratives, each of the participants was interviewed. The interview protocol consisted of fifteen structured open-ended questions.

\section{Author's Position as a Researcher}

As a researcher, the author had a responsibility to ensure the transparency and credibility of the study. Building up rapport with the participants in qualitative research is essential, but she was conscious of her familiarity impacting objectivity. During the interview, there were some points where some common teaching experiences in Bangladesh were shared. However, the author was mindful about compromising her position as a researcher and had a concern for the credibility of the interpretation of the data (Kumazawa, 2013). Avoiding distortion and protecting the authenticity, an enabling discussion at a deep level of self-searching was persisted.

\section{Data Analysis Method}

1). Narrative enquiry: This qualitative study applied narrative enquiry for its personal and compassionate approach to investigating into teachers' personal experiences. Participants' revelation of their minds helps researchers to develop a macro and micro-analysis of their stories (Mishler, 1986). Teachers' self-reflections on their own experiences may enable them to go through a process of stepping back, description, reflection, analysis and above all, a kind of articulation of experiences (Freeman, 1991).

2). Thematic analysis: This study applied 'thematic analysis' to focus on the experiences, meaning and realities of research participants. It is an attempt to "theorize the significance of the patterns and their broader meanings and implications" (Braun \& Clark, 2006, p. 84). The data was analysed following Braun \& Clark's (2006) six-step framework: i) familiarising with data ii) generating initial codes iii) searching for themes iv) reviewing themes v) defining and naming themes vi) producing the report

3). Theoretical framework of the study: Dornyei's (2005, 2009) L2 Motivational Self-System is the theoretical framework in this study. To recall, Dornyei's (2009) proposes that motivation for L2 learning is mostly derived from an individual's perception of his/her possible selves especially where a discrepancy exists between one's actual self and ideal L2 self (Lamb, 2011). This theory allows very subtle and situated approach to the multidimensionality and complexities of L2 motivational orientations and diverse learning contexts in today's globalised world (Kumazawa, 2013).

To address the study aims, the nature of the teachers' dream for future selves are framed against Dornyei's conceptualisation of the three self-constructs. 

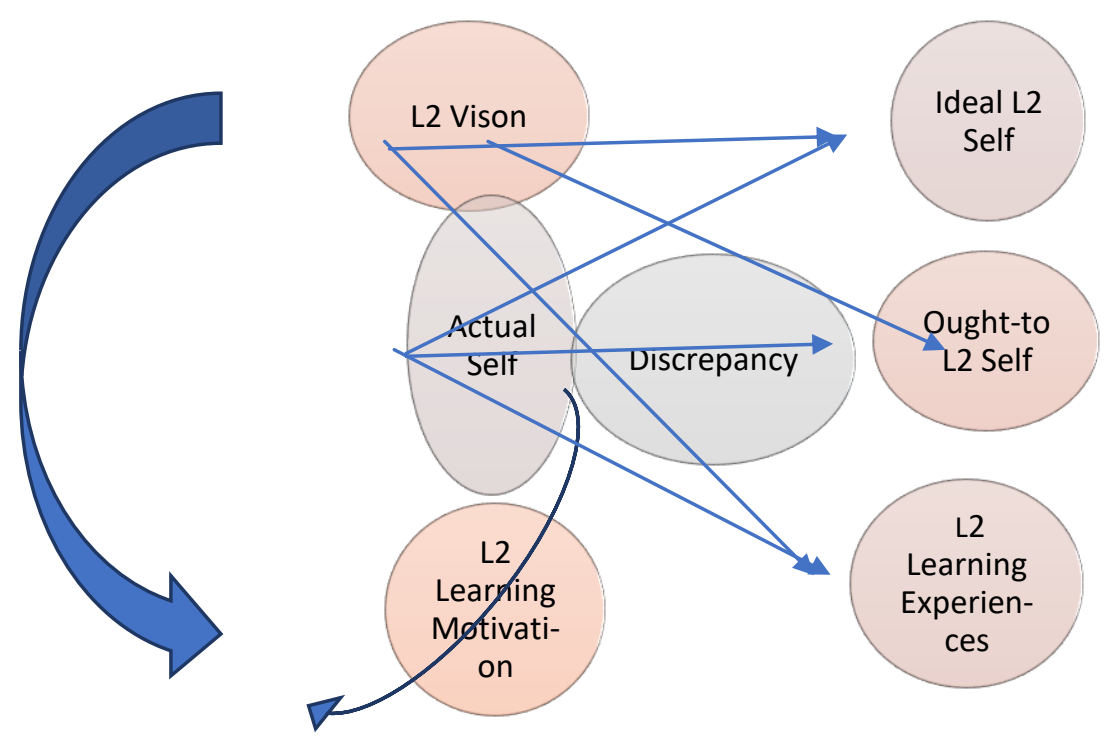

Figure 1: Dornyei's L2 Motivational Self System (author's own representation)

\section{RESULTS AND ANALYSIS}

\section{A. Answer to the Research Question 1}

Thematic analysis of data elicited three major themes regarding the English language learning experiences of the participants. These include:

1). Challenges of learning English: All the participants mentioned several common challenges in their L2 learning journeys: a) Lack of trained teachers and scarcity of learning resources b) Demotivation for learning English c) Sociocultural limitations.

The participants encountered considerable academic difficulties in learning English. Their memorisation based L2 learning was bound by the curriculum and syllabus. With regard to the academic compulsion, Moham said, "English was just a part of our academic process, not a meaningful way of communication. I had no purpose of communicating in English. I learnt English just as a subject". (Interview, August 15, 2019)

The school environment and classroom infrastructure were reported to be inappropriate for L2 learning by Priam, Mohan, Neha, and Fima. Noticeably, these three participants received their primary and secondary education in rural areas of Bangladesh. Mohan said:

The poor infrastructure of our classrooms did not provide a congenial environment for learning English. There was no speaking or listening practices in classroom. We were learning reading and writing to attend our school examinations. (Language biography, July 28, 2019)

Demotivation has been identified as another issue adversely impacting participants' L2 learning process. It often evolved from the teasing of classmates or the discouragement from English teachers at school. Neha said:

I used to try to speak English with my friends. I experienced some negative situations as they used to pull my legs, used to mock at me. I got demotivated to speak in English inside or outside the classroom. (Interview, September 4, 2019)

In Bangladesh, the social and cultural contexts did not appear conducive to L2 learning. Poor socio-economic status, disadvantaged family background, lack of parental care and support hindered Priam's L2 achievement. He mentioned his challenges both in his language biography and interview:

My rustic area had a little percentage of literacy. My parents were very simple and uneducated. They encouraged me to study English, but they could not show me the way. So, I had to shoulder everything on myself to improve my ability. (Interview, August 15, 2019)

2). Awareness of L2 learning in a globalised world: All the participants demonstrated their motivation for L2 learning having realised its global significance. Moreover, in Bangladesh, fluency in English is considered as a sign of social standing. Priam was found to be persuaded by the demand of English. He wrote:

English has an influence on rapid communications and job market. The demand of English was always higher to compete. Thus, being English language expertise was an ideal fascination to the participant by developing his capacitybuilding. (Language biography, July 30, 2019) 
Fima, mentioned the origin of her self-motivation for L2 learning. She reported, "In this age of globalisation, we cannot survive without knowledge in English. It is the gateway to success. So, we learnt it." (Language biography, August 5)

3). Self motivation: Despite demotivating issues, the awareness of the significance of English prompted the participants' L2 learning progress significantly. Fima said, "self-motivation stimulated me, and I helped myself." (Language biography, August 2, 2019). Priam wrote, "I was motivated, and self-motivation was the yardstick behind my success." (Language biography, July 30, 2019)

\section{B. Answer to the Research Question 2}

1). Vision of 'Ideal L2 Selves': According to Dornyei (2009), when an individual desires to become a fluent L2 speaker, 'Ideal L2 Self' becomes a powerful motivator and their L2 motivation springs from their attempts to reduce the discrepancies between one's 'Actual self' and 'Ideal L2 self' (p.29). Priam was found having an elaborate and vivid self-image for his possible L2 self. He dreamt of going to the UK or USA to undertake higher study and to be integrated to that society. He said:

I dreamt to speak fluently like the foreigners. I was amazed hearing the pronunciation of BBC news presenters. One English lady encouraged me to study English. I assumed that the British would be very civilised and good people and it fascinated me. (Interview, August 18, 2019)

In this concern, as Priam's vision involves his being a proficient L2 speaker and his engagement with UK or USA community, his vision can be identified with the 'Ideal L2 Self'.

Mohan, like Priam, possessed a clear image of future L2 self. He dreamt of speaking fluent English like the commentators on international cricket events. He could reflect on the discrepancy between his 'actual self' and 'Ideal L2 Self'. The aforementioned desire to speak English as native speaker as well as a dream to go to an L2 country identifies Mohan's vision as the 'Ideal L2 Self'.

Neha dreamt of being a fluent L2 speaker as English movie actors and English news presenters on television. She studied English literature and eventually developed an interest to know more about anglophone life and culture. She said:

When there was English news telecasted on television, it inspired me much as I dreamt to be like those news presenters. (Interview, September 4, 2019)

2). L2 learning experience: According to Dornyei (2009, p. 29), L2 Learning Experience concerns learners' situated, 'executive' motives which are related to the impact of the curriculum, the teachers, the peers or the success experiences. Among the participants, Shormi was found to have a desire to be a good L2 speaker being influenced by her schoolteacher and family members. She said:

No, I didn't have that kind of dream, but one of my teachers used to encourage me a lot. When I was a child, my father and uncle acted as my stimuli for L2 learning. (Interview, August 27, 2019)

Shormi's experiences did not associate English with any particular self-image of any ideal L2 speaker; rather her motive was related to her immediate learning environment and experiences with family members and teacher. So, her experience can be classified as 'L2 Learning Experience'.

Fima dreamt of being smarter than others with the ability in English. The rising demand of English for globalisation influenced her to be competent for the job market. She studied English literature and had an interest to know about English life and culture, but there was no clarity of her self-image or future self-guides. Fima's vision relates to her immediate learning environment and experiences which identify her L2 self-construct as 'L2 Learning Experience.

\section{Answer to the Research Question 3}

1) Visions and motivations: Concerning the relationship, Priam, Fima and Neha's visions related to their motivations but Mohan's and Shormi's visions had no relation to their becoming EFL teachers. Priam was determined to be an English teacher. He declined a banking job, although he qualified for it. He acknowledged:

Yes, I had a vision to be a teacher of English. When I was a student of Grade 11 and 12, I dreamt to be a teacher. I was offered some other banking jobs but declined those jobs. I wanted to be a teacher. (Interview, August 18, 2019)

His vision had clarity and had a connection with his motivation for teaching profession. Unlike Priam, Mohan did not show any relation between his vision and motivation. He had a vivid and clear vision of an 'Ideal L2 Self' but this had no link with his motivation for becoming an English teacher. He said, "I never dreamt to be a teacher. It was a coincidence. As a profession, I preferred to be a civil servant." (Interview, August 15, 2019)

His negative attitude to teaching profession became clear when he reported:

From my perspectives, environment, culture, and surrounding, nothing motivates us to be a proactive English teacher. Even not the salary encourages me. The poor infrastructure, no microphone with 400 students in a small room does not support me. So, nothing encourages me to be a motivated teacher. (Interview, August 15, 2019)

Thus, Mohan's vision does not relate to his motivation for teaching. In contrast, Fima was desirous of being an English teacher. Her personal hardship of learning English inspired her dream to be a teacher. She was motivated to help students in building their better future. She expressed her contentment with confidence:

Yes, I wanted to be a teacher to help students in building better future. . . I feel happy. I share my positive experiences with my students, and I enjoy it. (Interview, August 22, 2019) 
She demonstrated a strong desire to be a teacher and contribute to students' English competence. Thus, Fima's vision relates to her motivation to be an English teacher. Shormi wanted to be a doctor, not an English language teacher. She chose the teaching profession having no other alternative. She said: "No, I did not dream to be a teacher. Actually, I had no other option." (Interview, August 27, 2019). Shormi's vision and motivation for teaching had no connection. Neha demonstrated a strong determination to be a teacher of English. Her positive attitude to this language and awareness of its potential motivated her. She said:

I thought if I could be a good teacher, I could help others. There is a scarcity of good teachers of English. I thought I would learn more and teach others well. (Interview, September 4, 2019)

Neha wanted to be a role model for her students in the same way her schoolteacher had been a role model for her. Thus, Neha's experiences demonstrated a clear relationship between her vision and motivation to be an EFL teacher.

\section{Answer to the Research Question 4}

1). L2 visions and classroom teaching: Among all, Priam, Mohan, and Neha established a clear link between their L2 visions with their classroom teaching to motivate students. Priam was enthusiastic to generate awareness among his students about constructing an 'Ideal L2 Self' image which would act as their future self-guides. Priam reported that he shared his personal stories of L2 vision and learning experiences with his students:

Yes, I try to tell my vision and motivation for learning English among my students. Some students who are selfmotivated and committed, accept this positively. I believe that my motivational experiences impacted positively to become successful. I served as their role model. (Interview, August 18, 2019)

In this way, Priam's own L2 vision and motivation and his endeavour to motivate students in his classroom are explicitly related.

Again, Mohan tried to bridge his L2 vision and his classroom teaching to envision his students. He shared his success story and rewards for L2 learning. Thus, Moham put effort to connect his vision and his classroom practice, though the lack of feedback was discouraging for him.

Fima shared her L2 learning experiences with her students to motivate them. However, she appeared to establish no link between her own L2 visions and the way of motivating students. Noticeably, she felt discouraged by students' demotivation. She reported:

I share my language learning story and the positive experiences with students. However, not only the lecture can motivate them, they need practical learning ... There is no activity, no digital equipment in the class to entertain them. Lack of enjoyment bore them. It is difficult to motivate them. (Interview, August 22, 2019)

Fima demonstrated a concern for motivating students but without any effort to inspire students with any 'Ideal L2 Self' that could work as their future self-guide. So, her vision and classroom practices are not explicitly related.

Shormi was not found to make a link between her vision and classroom teaching. She even did not possess any clear Ideal L2 self. She tried to guide students with her positive experiences and create a fear-free learning environment. Shormi appeared to be a confident teacher with her effort to motivate students but her contribution to students' construction of self-images or L2 vision did not appear.

Neha tried to set example of an Ideal L2 self to help her students' formation of visions. She believed that she could motivate some of her students to be teachers in future as she explained:

I try to connect them. I teach them if they like the language, love the language. Thus, I try to motivate them...Some students are motivated, and want to be good teachers (Interview, September 4, 2019)

\section{DISCUSSION}

\section{A. The Early Language Learning Experiences of Bangladeshi EFL Teachers}

The findings show considerable difficulties in L2 learning encountered by the teachers. The socio-cultural context of Bangladesh presented an additional barrier to the participants' L2 learning. English is not used for social communications, and hence language learners have little to no access to practise English in real life situations (Rahman, 2005). Rahman, Rahman, \& Begum (2015) study found that students are usually shy about speaking at their initial stage as they are afraid of teachers' and peers' criticism.

The geographical location impacted on the participants' learning experiences. Hossain (2016) study found that the students from poor families in rural areas have scarce access to learning resources compared to the urban students. Uneducated parents and poverty impacted on Priam's study. Hossain (2016) study also found that low performance of rural students related to their parents' education and parents' low expectations influenced students' decisions to pursue education. Gender issue is a great concern and is even more acute in rural Bangladesh. Dejaeghere and Lee (2011) study in a rural district in Bangladesh, found that the girls and their parents experience insecurity on the way to school, the lack of free movement in communities, sexual harassment, and acid throwing. The underlying reasons for girls' being victims of violence relate to the attempt to abstain girls from becoming educated and changing social norms. Further empirical research with a larger sample of women would be an important issue to explore if the issues Fima raised, are experienced by others in similar circumstances.

Despite the challenges, all the participants were motivated to continue learning English beyond high school, stating a desire to compete on a larger scale within a more globalised context. In fact, with the rising demand for global and 
intercultural communications, English has become the 'lingua franca' and also has become an essential skill to create global citizens (Dower \& Williams, 2002; Mayo, 2005). Like many other third world countries, Bangladesh has redesigned its education policies with significant amendments to respond to this demand (Akteruzzaman \& Islam, 2017). For example, amendment in the national curriculum, in the introduction of English translations of Bengali textbooks, in the late 1990s, the enactment of the Private University Act in 1992, and the establishment of compulsory English courses in all universities in 1994 (Rahman, 2015). These initiatives exercised compelling influence on learners to consider English knowledge as mandatory for their career and survival in the global world (Akteruzzaman \& Islam, 2017).

\section{B. Future Visions: Participants' Self-perceptions of Possible Selves}

The participants' visions of possible selves have been investigated against Dornyei's L2MSS theory. Dornyei (2009) mentioned six conditions required to make the 'Ideal L2 self' active: (i) the L2 learner possesses a desired future selfimage; (ii) the self-image is vivid and precise; (iii) the self-image is considered as plausible and does not conflict with the learner's social environment; (iv) it is regularly activated; (v) it is associated with appropriate procedures towards the goal; (vi) it contains information about the adverse outcome of failure to meet the goal.

When a learner's ideal self involves a person, who is active and proficient in the L2 or his/her engagement with the L2 community, in Gardners' terminology he/she has an 'integrative' disposition (Nicholson, 2013, p. 280). Priam, Mohan, and Neha viewed themselves as native L2 speakers who could speak English fluently. They possessed elaborate and vivid self-images for the future, discovered gaps between their actual and desired L2 selves, strengthened their visions and took action to fill those gaps.

Fima's and Shormi's self-perception demonstrated their situated and executive motives and did not have any internally or externally generated self-images. Dornyei suggested that for some L2 learners, the primary motivation does not come from self-image but from successful involvement with the actual learning process and engagement with the learners' immediate learning environment $(2009$,$) .$

Markus (2006) argued that the dream or image of a desired future is the core content of the ideal self. At the time of their identity construction, adolescents produce diverse possible selves as alternative potential identities to discover and try out (Dunkel et al. 2006). "Individuals' representations of what is possible for the self, give rise to generalised feeling of efficacy, competence, control, or optimism" (Ruvolo \& Markus, 1992, p. 96). When students form their visions of possible selves, they start to consider learning as a way to activate their desires and aspirations and avoid feared possible selves. The participant's comments emphasised their willingness and commitment to learning English because the learning process and the end result reinforced their self-perceptions and provided a clear route towards their personal goals.

\section{Visions and Motivations to be English Teachers}

Teachers' self-perceptions, positive motivation, and professional commitment all combine to enhance their efforts to motivate students. Although this holds true on a general basis, within the context of this study, the teachers saw themselves as L2 learners first and teachers second. Rahmati et al. (2018) study explored the relation between teachers' visions of themselves and their motivations for teaching. In this study, the teachers' vision was identified as Ideal L2 teacher self-image. These researchers identified four categories of teacher vision - Visionary, Partially visionary, Vision-comprised, and Non-visionary. Teachers who had clear visions of their Ideal L2 teacher selves, were highly motivated L2 teachers. In my study, teachers have shared their experiences as L2 learners and teachers as well.

In Rahmati et al. (2018) study, it was found that teachers who had clear visions of Ideal L2 teacher selves, were highly motivated L2 teachers. In my study, the teachers' 'Ideal L2 Self' was considerably influential in their L2 motivation. However, it did not influence their decisions to enter the teaching profession. Teachers who had 'Ideal L2 Selves' visions, were found more aware of linking their classroom teaching with their visions to help students' formation of self-images.

It is clear that not all the participating teachers in my study were motivated L2 teachers. The reasons for their demotivation included lack of social recognition, learners' demotivation, learners' heterogenous level of L2 proficiency, infrastructural limitations, and crowded classrooms. In Sugino (2010), Wyatt (2013), and Rahmati et al. (2018) studies, similar factors were found to cause teachers' demotivation.

\section{Teachers' Visions Influencing Classroom Practice and Student Motivation}

Dornyei argued that 'it is more effective to raise awareness and guide in selecting from adolescents' dreams, aspirations and desires which already exist in them" (Dornyei, 2009, p. 33). Within the participant group, Priam, Mohan, and Neha reflected on their individual L2 visions, motivations and connected these visions with their classroom practices, helping their students to create their own visions in turn.

Teachers can ignite students' visions and contribute to their awareness of their own ideal selves and guide the students towards attaining that desired self-construction (Dornyei, 2009). Teachers' help in students' synthesis of potential hypothetical images to strengthen their visions and minimise weaknesses has been emphasised in other L2 motivational studies (eg.Oyserman et al. 2002). In my study, an alignment of vision and classroom practice was 
established and a transfer of motivation from teacher to student was found in Priam's, Mohan's, and Neha's case. They consciously linked their visions and teaching practices.

Although this study did not find a general alignment between teachers' visions, motivations and classroom practices across the participant group, those who constructed 'Ideal L2 Selves' in their own learning stages, could relate their classroom practices to these Ideal Selves and in turn help students' formation of L2 vision.

\section{IMPLICATIONS AND RECOMMENDATIONS}

Theoretically, the findings of this study emphasise the significance of vision construction for L2 achievement. Teachers can contribute to improving learners' motivational status by helping their formation of L2 visions. Moreover, intervention of 'language vision programmes' could be considered. Effective steps need to be initiated by educational authorities, and school administrators on how to provide conducive work environment encouraging for teachers' professional practices and endeavouring to motivate learners. Methodologically, narrative enquiry helped to uncover the teachers' in-depth thoughts, motivations and self-perception. Understanding the realities of teachers' professional motivation and their contribution to the construction of students' L2 vision could provide a starting point for further investigations. Practically, there was a noted difference between the motivational level of rural and urban students. Further research is required to consider the implications for improving facilities for L2 teaching and learning in Bangladeshi rural schools. The gap between urban and rural L2 access and support could be considered a social justice issue. Reducing that gap needs to be ensured in both rural and urban schools if the motivational level of both teachers and students is to be improved.

\section{CONCLUSION}

The study objectives of exploring Bangladeshi EFL teachers' L2 learning experiences, L2 visions, professional motivations and how these translate into classroom practices involved intensive self-searching for the five teachers in this study. The experience itself may be of value as a "journey into the deepest recesses of one's self-awareness" (Kagan, 1992, p.164). Self-searching in this way might contribute to increased teachers' awareness and a willingness to adapt their classroom practices to improving students' L2 motivation.

The teachers reflected on their experiences as both L2 learners and teachers, focusing on their past and their present and their interconnections. The teachers faced considerable challenges in their L2 learning journeys, but they improved their motivational states and formed their visions either of 'Ideal L2 Selves' or 'L2 Learning Experiences'. None of the participants admitted to the existence of 'Ought-to L2 Self' in their self-constructed visions. They did not share the same level of motivation or interest in their teaching and were not equally aware of using visionary tactics to encourage L2 learning in students. Teachers with 'Ideal L2 Selves' were more aware of generating their students' L2 visions. Being aware of their 'Ideal L2 Self' appeared to be a strong motivational force for the teachers.

The study also revealed teachers' lack of motivation for teaching as a profession. Professional motivation and commitment appeared to be based on social, economic, psychological, infrastructural, and cultural issues. Many of these challenges could not be addressed by the teachers themselves. Therefore, this study concludes with some recommendations to address these conditions at an institutional and political level to bring attitudinal change among those teaching English in Bangladesh. That positively motivated English teachers can play a significant role in motivating students by helping the construction of their visions for English learning, is not a hypothesis, rather it is a reality.

\section{REFERENCES}

[1] Ahmad, S. (2005). A study on motivation of the EFL learners at higher secondary level in Bangladesh. (Master's thesis, Jahangirnagar University, Dhaka, Bangladesh). Retrieved June 24, 2019 from https://files.eric.ed.gov/fulltext/ED545542.pdf.

[2] Akteruzzaman, M., \& Islam, R. (2017). English, education, and globalisation: A Bangladesh perspective. IAFOR Journal of Education, 5(1), 185- 206. Retrieved August 15, 2019 from https://files.eric.ed.gov/fulltext/EJ1141685.pdf.

[3] Bada, D., \& Olusegum, S. (2015). Constructivism learning theory: A paradigm for teaching and learning. IOSR Journal of Research \& Method in Education, 5(6), 66-70. Retrieved July 12, 2019 from www.iosrjournals.org.

[4] Bereiter, C. (1994). Constructivism, socioculturalism, and Popper's World 3. Educational Researcher, 23(7), 21-23.

[5] Braun, V., \& Clark, V. (2006). Using thematic analysis in psychology. Qualitative Research in Psychology, 3, 77-101.

[6] Clarke, V., V. Braun, and N. Hayfield. (2015). "Thematic Analysis.” In Qualitative Psychology: A Practical Guide to Research Methods, edited by J. Smith, 222-248. 3rd ed. London: Sage.

[7] Cook, D. A. \& Artino, A. R. (2016). Motivation to learn: an overview of contemporary Theories. National Library of Medicine, 50(10): 997-1014.doi: 10.1111/medu.13074.

[8] Das, B. B. (2001). Teaching of English in Bangladesh: Evaluation of Higher Secondary Pedagogy. Unpublished Ph.D. Thesis. Centre of Linguistics and English, Jawaharlal Nehru University, New Delhi.

[9] Deci, E. L., \& Ryan, R. M. (1985). Intrinsic motivation and self-determination in human behavior. New York: Plenum.

[10] Dejaeghere, J. \& Lee, S.K. (2011). What matters for marginalized girls and boys in Bangladesh: A capabilities approach for understanding educational well-being and empowerment. Research in Comparative and International Education, 6(1), https://doi.org/10.2304/rcie.2011.6.1.27.

[11] Dörnyei, Z. (1990). Conceptualizing motivation in foreign language learning. Language Learning, 40, 46-78. 
[12] Dornyei, Z. (1994). Motivation and motivating in the foreign language classroom. The Modern Language Journal, 78(3), 273284.

[13] Dornyei, Z. (1998). Motivation in second and foreign language learning. Lang. Teach. 31, 17-135.

[14] Dornyei, Z. (2001). Teaching and Researching Motivation. Harlow: Longman.

[15] Dörnyei, Z. (2005). The psychology of the language learner: Individual differences in second language acquisition. Mahwah, NJ: Lawrence Erlbaum.

[16] Dörnyei, Z. (2009). The L2 motivational self-system. In Z. Dörnyei\& E. Ushioda (Eds.), Motivation, language identity and the L2 self. Bristol: Multilingual Matters.

[17] Dornyei, Z., \& Chan, L. (2013). Motivation and vision: an analysis of future L2 self-images, sensory styles, and imagery capacity across two target languages. Language Learning 63(3), 437-462. doi: 10.1111/11ng.12005.

[18] Dower, N., \& Williams, J. (2002). Global Citizenship: A Critical Introduction. NY: Taylor \& Francis.

[19] Dunkel, C., Kelts, D., \& Coon, B. (2006). Possible selves as mechanisms of change in therapy. In C. Dunkel and J. Kerpelman (Eds.), Possible selves: Theory, research and applications (pp.187-204). New York: Nova Science.

[20] Fletcher, S. (2000). A role of imagery in mentoring. Career Development International, 5(4-5), 235-243.

[21] Freeman, D. E. (1991). "To make the tacit explicit:" Teacher education, emerging discourse, and conceptions of teaching. Teaching and Teacher Education, 7, 439-454.

[22] Gardner, R. C. (2010). Motivation and Second Language Acquisition: The Socio-educational Model. Switzerland: Peter Lang

[23] Haq, M. (2004). A baseline survey of rural secondary schools: A quest for teaching-lea rning quality. Bangladesh Educational Journal, 3(2), 31-54.

[24] Hiver, P. (2013). The interplay of possible language teacher selves in professional development choices. Language Teaching Research, 17(2), 210-227.

[25] Hussain, M.M. (2016). English language teaching in rural areas: A scenario and problems and prospects in contexts of Bangladesh. Advances in Language and Literary Studies, 7(3), Doi: 10.7575/aiac.alls.v.7n.3p.1.

[26] Kagan, D.M. (1992). Professional growth among preservice and beginning teachers. Review of Educational Research, 62(2), 129-169.

[27] Kubanyiova, M. (2009). Possible selves in language teacher development. In Z. Dörnyei\& E. Ushioda (Eds.), Motivation, language identity and the L2 self (pp. 314-332). Bristol, England: Multilingual Matters.

[28] Kumazawa, M. (2013). Gaps too large: Four novice EFL teachers' self-concept and motivation. Teaching and Teacher Education, 33, 45-55.

[29] Lamb, M. (2011). Future selves, motivation and autonomy in long-term EFL learning trajectories. In G. Murray., X. Gao., \& T, Lamb. (Eds.), Identity, Motivation and Autonomy in Language Learning (pp.213-227). Bristol: Multilingual Matters.

[30] Lamb, M. (2017). The motivational dimension of language teaching. Lang. Teach, 50(3), 301-346. Doi: $10.1017 / \mathrm{s} 0261444817000088$.

[31] Maniruzzaman, M. \& Haque, S. M. F. (2000). Attitudinal and motivational impact on EFL proficiency of undergraduates: A preliminary investigation. Journal of the Institutes of Modern Languages, 5-30.

[32] Markus, H., \&Nurius, P. (1986). Possible selves. American Psychologist, 41(9), 954- 969.

[33] Markus, H., \& Wurf, E. (1987). The dynamic self-concept: A social psychological perspective. Annual Review of Psychology, 38(1), 299-337.http://dx.doi.org/10.1146/annurev.psych.38.1.299.

[34] Maxwell, J. A. (2005). Qualitative research design: An interactive approach (2 ${ }^{\text {nd }}$ ed., Vol. 41). Thousand Oaks, CA: Sage.

[35] Mayo, M. (2005). Global citizens: Social movements and the challenge of globalisation. Toronto: Zed Books.

[36] Mishler, E. (1986). Research interviewing: context and narrative. Cambridge, Mass: Harvard University Press.

[37] Nicholson, S.J. (2013). Influencing motivation in the foreign language classroom. Journal of International Education Research, 9(3). 277-286.

[38] Oyserman, D., Coon, H. M., \& Kemmelmeier, M. (2002). Rethinking individualism and collectivism: Evaluation of theoretical assumptions and meta-analyses. Psychological Bulletin, 128, 3-72.

[39] Peng, J. (2015). L2 motivational self- system, attitude, and affect as predictors of L2 WTC: An imagined community perspective. Asia-Pacific Edu Res, 24(2), 433-443. DOI: 10.1007/s40299-014-0195-0.

[40] Quadir, M. (2017). Let us listen to our students: An analysis of demotivation to study English in Bangladesh. The English Teacher, 46(3), 128-141.

[41] Rahman, S. (2005). Orientations and motivation in English language learning: a study of Bangladeshi students at undergraduate level. Asian EFL Journal, 7(1), 29-55

[42] Rahmati, T., Sadeghi, K., \& Ghaderi, F. (2018). English language teachers' vision and motivation: Possible selves and activity theory perspectives. RELC Journal, 1-18. DOI: 10.1177/0033688218777321.

[43] Rahman, S. (2007). ELT in Bangladesh: A Socio-psychological study of public and private universities in Dhaka. Unpublished Ph.D. Thesis. Jawaharlal Nehru University, New Delhi.

[44] Rahman, S. S. (2015). Job satisfaction: A study of government college teachers in Bangladesh. (Unpublished master's thesis). North South University, Dhaka, Bangladesh.

[45] Rahman, M. Z., \& Rahman, A.M., \& Begum, M.K. (2015). Enhancement of students' English speaking in Bangladesh: Theory and practices. Manarat International University Studies, 5(1), Retrieved August 15, 2019 from http://miurs.manarat.ac.bd/download/Issue-05/12.pdf.

[46] Ruvolo, A. P. \& Markus, H. R. (1992). Possible selves and performance: The power of self-relevant imagery. Social Cognition, 10(1), 607-617.

[47] Seidman, I. (2006). Interviewing as qualitative research: A guide for researchers in education and the social science (3rd ed.). New York, NY: Teachers College Press.

[48] Sil, N. C. (2017). Use of motivational strategies in English classroom: Perceptions of Bangladesh Secondary school English teachers and students (Master's Dissertation). BRAC University, Dhaka, Retrieved June 17, 2019 from dspace.bracu.ac.bd/xmlui/handle/10361. 
[49] Stake, R. E. (1995). The area of case study research. Thousand Oaks, CA: Sage.

[50] Sultana, S. (2014). English as a medium of instruction in Bangladesh's higher education: Empowering or disadvantaging students? The Asian EFL Journal Quarterly, 16(1), 11-52.

[51] Sultana, N. (2018). Test review of the English public examination at the secondary level in Bangladesh. Language Testing in Asia, 8(16), https://doi.org/10.1186/s40468-018-0068-1.

[52] Tam, M. (2000). Constructivism, instructional design, and technology: Implications for transforming distance learning. Educational Technology and Society, 3(2), 50-60.

[53] Thompson, A.S. \& Vasquez, C. (2015). Exploring motivational profiles through language learning narratives. The Modern Language Journal, 99(1), DOI: 10.1111/modl.12187.

[54] Ushioda, E. (1998). Effective motivational thinking: A cognitive theoretical approach to the study of language learning motivation. In E. Alcón\& V. Codina (Eds.), Current issues in English language methodology (pp. 77-89). Castelló de la Plana, Spain: UniversitatJaume I.

[55] Ushioda, E. (2009). A person-in-context relational view of emergent motivation, self and identity. In Z. Dörnyei\& E. Ushioda (Eds.), Motivation, language identity and the L2 self (pp. 215-228). Bristol: Multilingual Matters.

[56] White, C., \& Ding, A. (2009). Identity and self in e-language teaching. In Z. Dornyei, \& E. Ushioda (Eds.), Motivation, language identity and the L2 self. Bristol, England: Multilingual Matters.

[57] Winchester, J. (2012). The potential impact of the teachers on student identities in the classroom in an English language teaching context. TESOL Journal, DOI 10.1002/tesj.64.

[58] Wyatt, M. (2013). Motivating teachers in the developing world: Insights from research with English language teachers in Oman. Int Ref Educ, 59, 217-242. DOI 10.1007/s11159-013-9358-0.

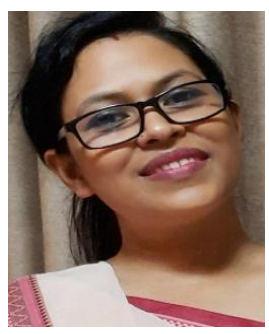

Beauty Debnath was born in Mymensingh, Bangladesh. She received her BA honours and MA degree in English literature from National University of Bangladesh. She was awarded with prestigious 'Australia Awards Scholarship 2018' and had completed Master of Educational Studies with TESOL Major from Griffith University, Queensland, Australia.

She joined Bangladesh civil service (Education Cadre) in 2006 and has been working as an Assistant Professor of English in different public colleges. Her current working place is Directorate of Secondary and Higher Secondary Education, Bangladesh, Dhaka. Her research interests include EFL teachers' agency, professional identity and professional development.

She was awarded with 'Griffith Academic Excellence Award 2019' from Griffith University, QLD, Australia and was also awarded with 'The Chairman's Award' in 2010 for obtaining topmost position in Foundation Training Course organised by National Academy for Educational Management, Dhaka, Bangladesh. 